\title{
Migration Due to Climate Change from the South-West Coastal Region of Bangladesh: A Case Study on Shymnagor Upazilla, Satkhira District
}

\author{
Most. Nasima Akhter ${ }^{1}$, Tapos Kumar Chakraborty ${ }^{2, ~ *}$, Gopal Chandra Ghosh ${ }^{2}$, Prianka Ghosh ${ }^{2}$, \\ Sayka Jahan ${ }^{2}$ \\ ${ }^{1}$ Department of Sociology, Baliadanga Khanpur College, Monirampur, Jessore, Bangladesh \\ ${ }^{2}$ Department of Environmental Science and Technology, Jessore University of Science and Technology, Jessore, Bangladesh
}

\section{Email address:}

juie69nasima@gmail.com (Most. N. Akhter), taposchakraborty@rocketmail.com (T. K. Chakraborty), gopales8@hotmail.com (G. C. Ghosh), priankaghoshest@yahoo.com (P. Ghosh), saykaes@yahoo.com (S. Jahan)

${ }^{*}$ Corresponding author

\section{To cite this article:}

Most. Nasima Akhter, Tapos Kumar Chakraborty, Gopal Chandra Ghosh, Prianka Ghosh, Sayka Jahan. Migration Due to Climate Change from the South-West Coastal Region of Bangladesh: A Case Study on Shymnagor Upazilla, Satkhira District. American Journal of Environmental Protection. Vol. 5, No. 6, 2016, pp. 145-151. doi: 10.11648/j.ajep.20160506.11

Received: September 25, 2016; Accepted: October 8, 2016; Published: November 1, 2016

\begin{abstract}
Climate change has been presented as a likely trigger for migration of people, especially in Coastal areas in Bangladesh. This study investigates the climate-induced migration causes, migration pattern and destination of individual household in coastal Bangladesh. It also identifies which economic groups were migrated from this region. Data were collected through a stratified random sampling technique on 120 rural households through a defined questionnaire survey. Survey was carried out aftermath of AILA ( $25^{\text {th }}$ May 2009), from three disasters prone unions in coastal Bangladesh. Findings showed that the main causes of migration were unemployment $(65 \%)$, poverty and food insecurity $(23 \%)$. The rate of temporary / seasonal migration $(67 \%)$ was higher than permanent migration $(20 \%)$ and most migrants choose city area $(77 \%)$ as their migration place. Mainly lower economic groups (Extremely poor, poor and lower middle class) were migrated from this region for economic insufficiency. Creating job facilities and ensuring food security is the main solution for improving this problem.
\end{abstract}

Keywords: Cross-Sectional Survey, Climate Change, Migration, Coastal Bangladesh

\section{Introduction}

Climate change has emerged as the greatest threat facing the mankind today [1]. The adverse effects of climate change undermine the economic development, human security, and people's fundamental rights [2]. It is a main obstructs for the achievement of the Millennium Development Goals (MDGs) of the least developed countries, who are highly vulnerable to the climate-induced disasters [3]. Disaster statistics show that the frequency and intensity of extreme natural events have been increasing in recent years [4]. Additionally, global climate change and sea level rise may affect low-lying and coastal countries as a result; millions of people are losing their homes, occupations and livelihoods [5]. The International Organization on Migration (IOM) has estimated that by 2050 there will be 250 million people who could be described as a climate or environmental migrants [6].

Bangladesh suffers from frequent natural hazards and its vulnerability to natural hazards also leads to climate displacement. The main causes of climate induced migration in Bangladesh are tidal flooding in the coastal areas and riverbank erosion in the mainland areas, on the other hands tropical cyclones and storm surges also responsible for migration from the coastal and mainland regions. In Bangladesh, 24 coastal and mainland districts out of 64 districts, are already producing climate displaced people [7]. It is predicted that $17 \%$ of the coastal area of Bangladesh may be inundated by 2050 if global warming cannot be 
reduced. In that case, the migration scenario might be worsened [8].

In Bangladesh more than 40 million people live in the coastal region where about $55 \%$ are live within the $100 \mathrm{Km}$ of $710 \mathrm{Km}$ long from coastal belt. Most of the coastal people are poor because they are dependent on the weather and natural resources [9, 10]. About 12 out of 19 districts are directly exposed to the sea for this reason, large-scale population displacement is occurring due to natural disaster [10]. The highest number of affected people has been recorded after 1990. About 8.7 millions of people of 30 districts from 64 districts were seriously affected by cyclone SIDR that hit in 2007. The cyclones that occurred in 1970, 1985, 1991, 1997, 2007 and 2009 caused huge losses and displaced millions of people from the coastal areas [11].

In 2007, the country was ravaged by Cyclone SIDR, which displaced 650,000 people and killed 3,447 (official record). In the year 2009, two cyclones hit the country (cyclone BIJLI, April 2009, and cyclone AILA, May 2009). About 200,000 people were displaced by cyclone BIJLI. In May 2009, cyclone AILA mashed the coastal area and nearly 4.82 million people were affected. The International Organization for Migration (IOM) has reported that a number of 11,118 families in Dacope upazila and 5,533 families in Koyra upazila were displaced in November 2009 as a direct consequence of the cyclone. According to the assessment of the European Commission's Humanitarian Aid Office (ECHO) partners, about 40,000 people migrated from Koyra upazila (sub-district) of Khulna district in Bangladesh due to the cyclone AILA [12]. In addition, a survey conducted in the cyclone AILA affected district of Khulna revealed that coastal water logging resulted in a huge population movement in nearby safer elevated places. Approximately 106,000 people were displaced from water logging in the area to nearby safer, dry places and other distant districts and in some cases, even in India [13].

In addition, Bangladesh is expected to have massive environmental displacement, which is calculated to be about 49 million, 63 million and 78 million in 2010, 2015 and 2020 respectively. The growth in environmental displacement is found to be $42 \%$ of the total populations in 2020, a startling fact indeed [11]. Migration is not new to Bangladesh. In this country, large-scale movement of the population has been a feature for a very long time [14]. The main objective of this paper is to examine the actual causes of climate induced migration, migration pattern, destination and identified which economic group have migrated from this region.

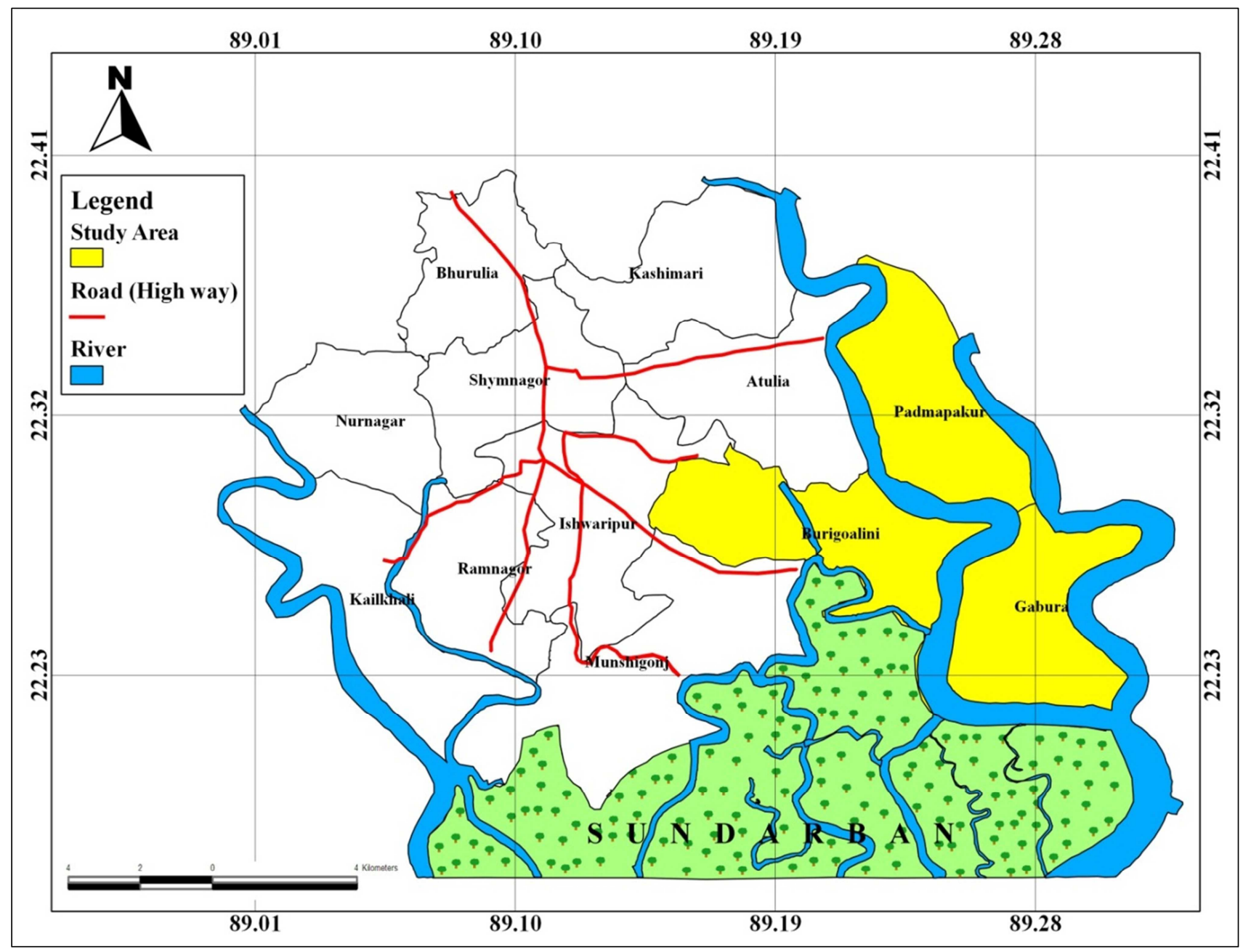

Figure 1. Map of selected study area (Shymnagor Upazilla of Satkhira district in Bangladesh). 


\section{Methodology}

The study has been conducted among Burigoalini, Padmapakur and Gabura Union ${ }^{1}$ of Shyamnagor Upazila ${ }^{2}$ in Satkhira district ${ }^{3}$. It is the last settlement areas in southern coast part of Bangladesh. People are mostly dependent on the resources of Sundarbans. Fishing, agriculture and nonagricultural laborers are widely practiced occupation in this community. A total of 37666 numbers of people lives in an area of $41 \mathrm{sq} . \mathrm{km}$. and all of them were affected by cyclone Aila and in the aftermath of the cyclone by water-logging. The literacy rates among the three unions are Burigoalini (38.93\%), Padmapakur (37.08\%) and Gabura (31.40\%). Sources of drinking water were tube well $(35.94 \%)$, tap $(6.46 \%)$, pond $(50.74 \%)$ and others $(6.86 \%)$ [15, 16, 17$]$.

The research was based on quantitative data and it was collected through household questionnaire survey. The questionnaire concentrated about respondent migration causes, migration pattern, destination, etc. Some data has been collected through self-observation in order to know the actual status of these regions. Both descriptive and inferential statistics were used to analyze the data. The total sample size of the household questionnaire survey was 120. From the selected household list, 120 semi-structured and open-ended questionnaires were administered randomly among household heads and permanent resident because they have a vast knowledge and experience regarding the impact of disaster on various sectors. Collected data were analyzed by Microsoft excel 2010 programme. Household heads were interviewed as they have a good sense of the household's vulnerability for their security and livelihoods. Samples were collected from three unions during October 2012 to December 2012. Out of the total respondents, approximately $83 \%$ were males and $17 \%$ were females. This reflects the fact that a woman rarely heads a household in Bangladesh.

\section{Results and Discussion}

\subsection{Demographic Profile of Surveyed Households}

Total 120 households were visited in 3 unions (Burigoalini, Gabura and Padmapakur) under shymnagor upazilla, approximately 40 households in each union. The age of the sample respondents were between 20 to 80 years old, with a mean age of 41 years. The numbers of male and female was $82 \%$ male and $18 \%$ female. A majority $92 \%$ of the respondent were Muslim and $8 \%$ were Hindu. In each place, however the number of males and females varied depending on household head that was available at home during the survey. The average family size was 4.7 where the national average rural family size, 4.89 , as found in the

\footnotetext{
1 Union is the third lowest tier of an official administrative unit of local government in Bangladesh.

2 The upazilas are the second lowest tier of the administrative unit of local government in Bangladesh.

3 The Districts are the first tier of the administrative unit of local government in Bangladesh.
}

recent Demographic and Health Survey [18]. In the study area $77 \%$ house were kucca (constructed by mud), $11 \%$ house was constructed by tin sheet (floor concrete, roof and wall were prepared by tin sheet), $7 \%$ were half concrete and $5 \%$ were full concrete house. About $41 \%$ family has no land for house construction, they stay on government land.

\subsection{Migration Causes}

After data analysis, it has been found that the main causes of migration from those areas were unemployment, fear of recurrent disaster, poverty and food insecurity (Fig. 2).

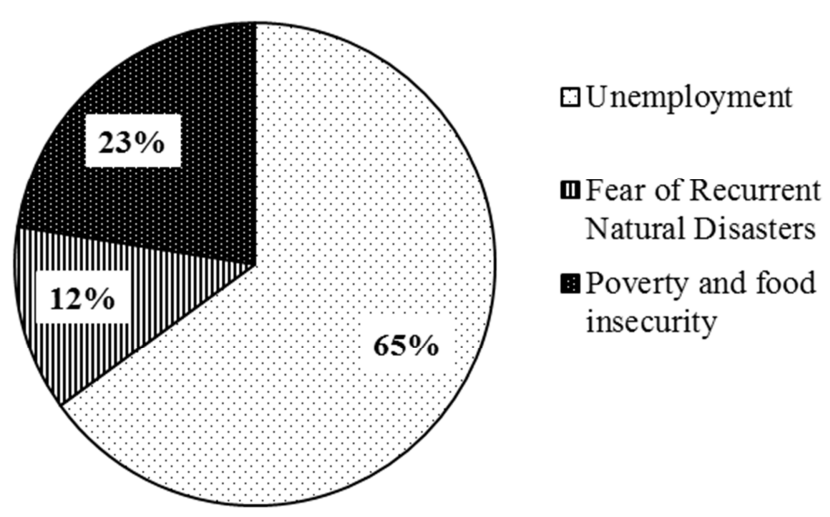

Figure 2. Migration causes in the selected study area.

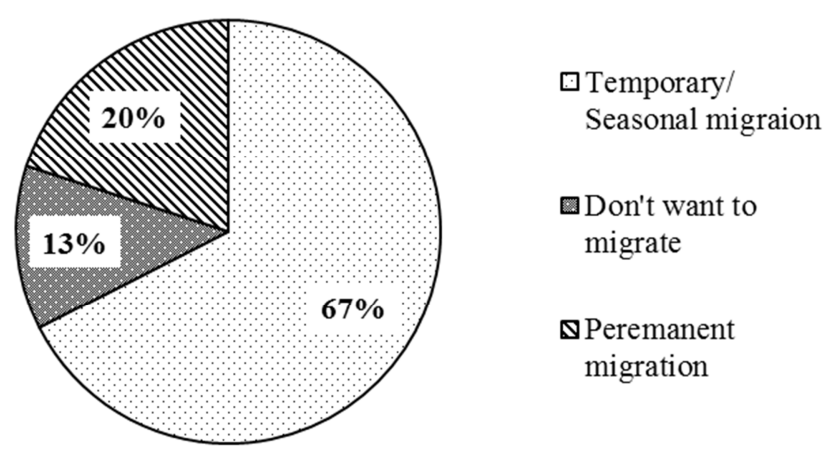

Figure 3. Migration pattern in the selected study area.

\subsubsection{Unemployment}

The prime cause of migration from this area was unemployment (65\%) (Fig. 2) because in the study, about most of the respondents have changed their occupation from agricultural farmer to day labourer. Occupational change can be considered as both secondary occupations and diversification of livelihood options. Though they chose day labourer as their secondary profession but it has a risk during critical time, e.g. no work during the rainy season or prolonged water-logging, the risk of being kidnapped while working in the Sundarbans (e.g. Fishing, collection of thatching materials and honey). The risk of livelihood diversification at the household level is associated with inadequate capital for investment, and lack of skills and education for the maintenance of the activities, e.g. integrated farming (poultry, fish and vegetable garden), or crab fattening, losses of agricultural land and lack of availability 
of working option. Success in those activities keeps people stable in the area, and failure leads to a transformation, e.g. migration [19]. On the other hands due to cyclone AILA, many people have lost their livelihoods in the agricultural sectors (Presented in Table -1). The conversion of coastal lands to shrimp farming has also increased unemployment. During filed investigation some respondents were saying that 20 people are needed for 7 acre paddy field cultivation, but one person is enough to conduct a shrimp farm for same cultivation. As a result, they have lost their livelihoods in agriculture and fishing and forced to search for alternative work as day labourers, or to migrate temporarily or permanently in search of alternative employment. Respondents also said job scarcity has been increased after cyclone AILA in a high rate.

Table 1. Occupational status in the selected study area.

\begin{tabular}{lll}
\hline Occupation option & Past occupation (before 15 to 20 year) $(\%)$ & Present occupation (\%) \\
\hline Agricultural labourer & $(\mathrm{n}=68), 57$ & $(\mathrm{n}=15), 13$ \\
Non-Agricultural labourer & $(\mathrm{n}=23), 19$ & $(\mathrm{n}=76), 63$ \\
Wood cutter & $(\mathrm{n}=10), 8$ & $(\mathrm{n}=8), 7$ \\
Fisher man & $(\mathrm{n}=9), 8$ & $(\mathrm{n}=10), 8$ \\
Honey collector & $(\mathrm{n}=4), 3$ & $(\mathrm{n}=5), 4$ \\
Business man & $(\mathrm{n}=6), 5$ & $(\mathrm{n}=6), 5$ \\
\hline
\end{tabular}

\subsubsection{Fear of Recurrent Natural Disasters}

In the study area, it has been found $12 \%$ were migrated due to the fear of recurrent disaster (Fig. 2) because the frequent and severe tropical storms with higher wind speeds and storm surges are increasing day by bay in the coastal regions. So it has a great possibility to occur extensive damage or losses of houses, property and infrastructure (house, sanitation facilities, drinking water sources. etc.), human life, livestock and agriculture and livelihoods. As a result, it's leading to the displacement of individuals and communities from their homes and lands [7]. Looking back, Cyclone SIDR in 2007, and Cyclone AILA in 2009 caused loss of life, livelihoods and property, thus pushing people to migrate from their origin. Repeated exposure to such disasters gradually declines the household's asset base and resilience capacity to make restoration very hard [20]. So people migrate from this place in order to escape this problem.

\subsubsection{Poverty and Food Insecurity}

About 23\% people said that poverty and food insecurity were the other reason for migration (Fig. 2). Respondent also said that coastal flooding and the intrusion of salt water on land are responsible for loss of cultivatable land and crop production than the past, $75 \%$ people said that their crop production are reduced, mainly after cyclone AILA. Although there is no official record of reduced agricultural output due to the salinity of the soil, analysts estimate the drop in agricultural production could be as much as 50 percent over the past 30 years [21]. While agricultural productivity has suffered, many areas have tried to evolve to maximize the opportunities available in their locality. In some cases farmers have chosen to shift from agricultural production to shrimp farming as a result of salinization. Yet it has provided economic benefits to some people, but it also led to food insecurity for others and rising unemployment. The combined effect of losing land to the sea and of other agricultural land declining in fertility inevitably leads to greater food insecurity which forced people to displace. According to [22] research into human security, food security was named as one of the five main problems facing nearly 40 percent of household survey respondents. About $43 \%$ people in the study area cannot properly manage three time meal in a day. Due to flooding \& prolonged water-logging in the southwest of Bangladesh basically, in Khulna and Satkhira district, food was identified as the first priority by the communities. Flood shocks and disasters in these poverty prone areas amplify food insecurity [23]. In other cases property is central to sustaining livelihoods and generating income. Any loss can decrease capability to fulfill basic needs, and can act as a poverty and unemployment multiplier. In many cases, the victims of naturally occurring hazards are forced to take out loans to replace their losses. These loans are often difficult to repay, which further decrease livelihood security as a result. People are choosing migration in order to avoid this problem.

\subsection{Migration Patterns}

In the study area, two types of migration were found (i) Temporary / Seasonal migration and (ii) Permanent migration.

\subsubsection{Temporary / Seasonal Migration}

Temporary migration is a traditional mechanism for sustaining livelihoods during periods of environmental insecurity. It usually comprises the short-term movement of one or two members of a family to a different location in order to find employment. In the study area, it has been found that about $67 \%$ people were migrated temporarily / seasonally (Fig. 3). Temporary migrants usually move to urban areas to seek employment in the informal sector (such as rickshaw driving) or to rural areas to take up employment as labourers on commercial farms. Migration is traditionally linked with seasons, where people migrate during the seasons that are unfavorable to work [20]. However, the field research shows that the number of people migrating temporarily from 
areas due to the negative impact of cyclone AILA because the local coping strategies have become more difficult to sustain. Although the decision to migrate temporarily is determined by a number of differing factors, the frequency and intensity of naturally occurring hazards have increased the pressure on people to relocate both temporarily and on a more permanent basis. In the study area temporary / seasonal migration pattern are present in Table 2.

Table 2. Temporary/seasonal migration pattern in the selected study area (Source: Based on respondent's opinion during field survey, 2012).

\begin{tabular}{|c|c|c|c|}
\hline Migration period & Type of works & $\begin{array}{l}\text { Length of Stay } \\
\text { (month) }\end{array}$ & Destinations \\
\hline $\begin{array}{l}\text { December-January and July- } \\
\text { August }\end{array}$ & Paddy sowing, day labour & 1 to 1.6 & $\begin{array}{l}\text { Gopalgonj, Faridpur, Madaripur, Narail, Netrokona, } \\
\text { Sylhet, Noakhali, Jessore, Bagherhat }\end{array}$ \\
\hline April- May & Paddy harvesting & 1 to 2 & \\
\hline October-November to April-May & Brick field & 5 to 7 & Dhaka, Barisal, Narail, Khulna, Noakhali, Delhi (India) \\
\hline November-March & $\begin{array}{l}\text { Wood processing work (with handy } \\
\text { chainsaw), day labour etc. }\end{array}$ & 1 to 2 & Bagerhat, Barguna, Gopalgonj, Barisal \\
\hline January-May & $\begin{array}{l}\text { Day labour (e.g. embankment, pond } \\
\text { excavation etc.) }\end{array}$ & 2 to 3 & Khulna, Bagerhat, Sathkhira \\
\hline \multirow{3}{*}{$\begin{array}{l}\text { Any time of the year but mostly } \\
\text { during rainy season (June- } \\
\text { August) }\end{array}$} & Day labour, rickshaw pulling & \multirow{3}{*}{1 to 12} & Dhaka, Khulna, Jessore, Satkhira \\
\hline & Sea port & & \\
\hline & Garments factory, industrial worker & & Dhaka, Chittagong, Maymansing \\
\hline
\end{tabular}

Temporal migrants generally send remittance. The majority of migrants are mostly used for daily expenses. They also use this money for food, loan repayment and others. However, it is viewed as a pillar which tackles the earning vulnerability in times of serious economic hardship. They think that it is the most benefit able option for poverty reduction than permanent migration because the living cost in urban area is higher than village area.

\subsubsection{Permanent Migration}

The study area report represents that, about $20 \%$ people were migrated permanently from this region to another region (Fig. 3). Respondent said that people are migrating permanently for shelter and employment opportunities, dream of better living conditions, access to facilities and amenities such as and better medical care etc. when a household lost everything, then they migrate permanently. Although seasonal migration is a well-established trend in Bangladesh, it appears that there has been a significant increase in permanent migration from areas affected by climate change. A study by the Bangladesh Institute for Development Studies shows that all types of migration have increased significantly over recent years. The findings from the field research suggest that migration is increasing in response to the severity of naturally occurring hazards and that this migration is becoming more permanent [24]. About $13 \%$ people don't want to migrate because their economic status is higher than other groups and they also able to recover any types of damaged (Fig. 3).

\subsection{Migratory Destinations}

Majority of seasonal and permanent migrants were going to city area about $77 \%$ (Fig. 4). Destination and occupation of seasonal migrants are not static in nature. In a year, some temporal migrants work at brickfield which is not so far from the village, but in another year same people go to the city area to work at a restaurant or rickshaw pulling. Even nature and types of work of day labor is changed within a week. However, it is proved that the majority of migrants are pouring into the city area. Not only temporary migrant but also permanent migrant also chooses city area for gathering more opportunities. Rural to urban migration is a common phenomenon and has been the most prevalent form of migration for a long time in Bangladesh for income generating opportunities $[19,24,25]$. Others migrated, migrate to nearby areas $(11 \%)$ for immediate shelter and still find out hope of source of income (Fig. 4), if their work is available, they chose this place, on the other hand, some migrant doesn't like city area because they can't adapt in this place. A few numbers of people are migrating to outside the country (India) 12\% (Fig. 4); some seasonal migrant was migrated to India for earning more money.

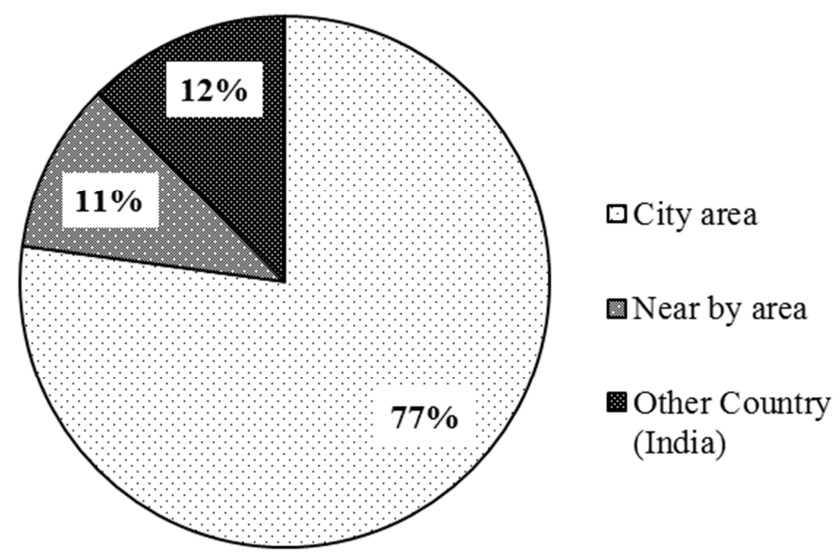

Figure 4. Migration destinations in the selected study area. 


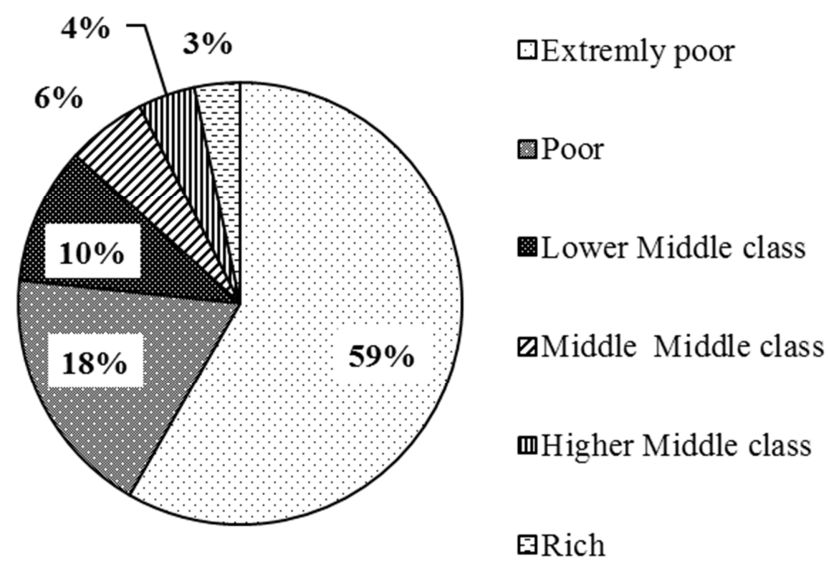

Figure 5. Economic groups in the selected study area.

\subsection{Who Had Been Migrated?}

Household economic conditions of coastal communities are different from the mainland of Bangladesh. The Coastal zone is relatively income-poor in comparison with the rest of the country. In this study household were categorized into six groups such as extremely poor, poor, lower middle class, medium middle class, higher middle class and rich (Fig. 5). According to [26] for developing country which household income USD 1.25 per day are called extremely poor and income USD 2 per day are called poor family. According to [27], satkhira district ranks as the highest in the country, at over $44 \%$ of the population being classified as extremely poor. In the field survey, it has been found that about $59 \%$ household were extreme poor ( $>38$ USD / month), $18 \%$ poor ( $<38$ USD to 63.33 USD / month), 10\% lower middle class ( $<63.33$ USD to 88.67 USD / month), $6 \%$ middle middle class ( $<88.67$ USD to 114 USD / month), $4 \%$ higher middle class (< 114 USD to 139.33 USD/ month) and $3 \%$ households were Rich (139.33+ USD /month) (Fig. 5). Extremely poor, poor and lower middle class economic families were suffer most from disaster impact, because they were not able to meet their family demand as a result, they were migrated from this reason, but other groups were economically strong, they can manage their problem, so migration was not mandatory for them. $\left(1 \mathrm{USD}^{4}=78.944\right.$ $\mathrm{BDT}^{5}$ in 2012).

\section{Conclusion}

At the end of the study, it has been found that the household economic condition is miserable because about $59 \%$ people live below the poverty line, $18 \%$ poor and $10 \%$ lower middle class, they were migrated from this reason due to insufficient income and unable to meet family demand. The main causes of migration were unemployment, poverty and food insecurity. Cyclone AILA altered their main occupation (Agricultural labourer to day labourer) and it's also responsible for house damages, property and

4 United Stated Dollar

5 Bangladesh Taka (Currency) infrastructure (house, sanitation facilities, drinking water sources, etc.), a high loss of human life and loss of livestock and disruption to agriculture and livelihoods. As a result, people couldn't adapt, they migrate to alternatives outside their origin, sometimes very long distances. In study area permanent migrations are occurring, mainly for economic reasons and pull factors, e.g. job, shelter, new land for landless. In the case of temporary migration some people need to look outside for short term work, while others go merely to increase their financial resources in the rural areas to gain additional savings to provide better support to their family. So migration is taking place primarily for economic reasons, which has been harshly disrupted by cyclone AILA. Both migrant (permanent and temporal) choose city area for gaining more benefit, but all of them of permanent migrant were settling in the slum area which is not hygienic and safe for them. The study suggests developing combined agricultural practices, creating job opportunities, increase disaster adaptive support for food and livelihood security, which will reduce the flow of temporary and permanent migration from the vulnerable coastal parts of Bangladesh.

\section{References}

[1] Clime Asia. Editorial: Clime Asia, A climate action networksouth Asia (CANSA) newsletter, BCAS. Dhaka. Bangladesh. 2009.

[2] UNDP. Climate change and the MDGs, United Nations Development Programme. 2007. Accessed 12 February 2014. Available: http://www.undp.org/gef/adaptation/dev/02a.htm.

[3] Vashist S, Das PK. South Asia needs greater cooperation to fight climate change. Clime Asia: Climate Action NetworkSouth Asia newsletter, BCAS. Dhaka. 2009.

[4] UNDP. A Global Report: Reducing Disaster Risk: A challenge for development. United Nations Development Programme, Bureau for Crisis Prevention and Recovery. New York. 2004.

[5] World Bank. Climate Change and impact on costal countries. World Bank. 2007. Accessed 9 January 2015. Available: http://econ.worldbank.org/WBSITE/EXTERNAL/EXTDEC/E XTRESEARCH/0,contentMDK:21215328 pagePK:64165401 $\sim$ piPK:64165026 theSitePK:469382,00.html.

[6] IOM. Compendium of IOM's activities in migration. Climate Change and the environment. International Organization for Migration (IOM), Geneva, Switzerland. 2009.

[7] Displacement Solutions. Climate Displacement in Bangladesh: The Need for Urgent Housing, Land and Property (HLP) Rights Solutions. 2012. Accessed 10 July 2013. Available: http://displacementsolutions.org/wpcontent/uploads/DS-Climate-Displacement-in-BangladeshReport-LOW-RES-FOR-WEB.pdf.

[8] Stern N. Stern Review on the Economics of Climate Change. London. October 2006.

[9] Hodgkinson D, Burton T, Anderson H, Young L. Hour When the Ship Comes In: A Convention for Persons Displaced by Climate Change. The Monash UL Rev. 2010; 36-69. 
[10] Comprehensive Disaster Management Programme (CDMP II). Trend and Impact Analysis of Internal Displacement due to the Impacts of Disaster and Climate Change. Ministry of Disaster Management and Relief, Dhaka. 2014.

[11] Akter T. Climate Change and Flow of Environmental Displacement in Bangladesh. Research Paper, Unnayan Onneshan, Dhaka, Bangladesh. 2009.

[12] Roy DC. Vulnerability and population displacements due to climate-induced disasters in coastal Bangladesh. Doctoral dissertation. University of Salzburg. United Nations University Institute for Environment and Human Security. United Nations University. Web, 3 Apr 2011.

[13] Kushol R, Kumar U, Mehedi H. Cyclone AILA: Initial Assessment Report with focus on Khulna district. Unnayan Onneshan, Humanity Watch and Nijera Kori, Dhaka. 2009.

[14] Begum A. Destination Dhaka, Urban Migration: Expectations and Reality. The University Press Limited. Dhaka, Bangladesh. 1999.

[15] DMB-GoB. National plan for disaster management 2010 2015. Disaster management bureau. Disaster management and relief division. Government of Bangladesh. 2010.

[16] CRF. Living with cyclone Aila. Coastal Research Foundation. Khulna, Bangladesh. 2010.

[17] Bangladesh Population Census. Cultural survey report of Shyamnagar Upazila. Bangladesh Bureau of Statistics. Dhaka, Bangladesh. 2001.

[18] Bangladesh Health and Demographic Survey. NIPORT. 2011.

[19] Walsham M. Assessing the Evidence: Environment Climate Change and Migration in Bangladesh. International Organization for Migration. Dhaka, Bangladesh. 2010.
[20] Mehdi A. Factors Driving Environmentally Induced Migration In The Coastal Regions of Bangladesh: AN Exploratory Study. Master's thesis. Albert-Ludwigs-Universität Freiburg. Germany. 2011.

[21] IRIN. Bangladesh Flood Migrants Pour into Dhaka In: IRIN. Published on 18.10. 2007. Accessed 15 November 2014. Available: www.irinnews.org/report.aspx?ReportId $=74846$.

[22] Saferworld. Human security in Bangladesh. 2008. Accessed 20 January $2014 . \quad$ Available: http://www.saferworld.org.uk/publications.php/323/human_se curity_in_bangladesh.

[23] Jannatul M. Elusive Progress: State of Food Security in Bangladesh, 2012. Unnayan Onneshan. Indira Road, Farmgate, Dhaka-1205, Bangladesh. 2012.

[24] Afsar R. Internal Migration and the Development Nexus: The Case of Bangladesh. University Press Limited. Dhaka. 2003.

[25] Sen B. Drivers of Escape and Descent: Changing Household Fortunes in Rural Bangladesh. World Development., 2003; 31 (3): 513-534.

[26] World Bank. Poverty Overview. 2011. Accessed 16 April 2015. Available: http://www.worldbank.org/en/topic/poverty/overview.

[27] World Food Program (WFP). Food Security at a Glance. 2012. Accessed on 01 May 2015. Available: http://foodsecurityatlas.org/bgd/country/food-security-at-aglance. 